Др Персида С. Лазаревић ди Ђакомо

\title{
ЗЛАТНАЈА КЬИЖИЦА (1813) ИЛИТИ СРПСКИ БОНТОН
}

У овом раду се анализира Злайнаја књижица (1813), српски превод дела итало-швајцарског педагога и писца Франческа Соавеа (1743-1806), Trattato elementare dei doveri dell'uomo e delle regole della civiltà (1786). Аутор превода је Доситејев најближи пријатељ и сарадник Павле Соларић (1779-1821), који је уз превод приложио Преgисловије у коме излаже о важности ове књижице. Својим преводом и предисловијем Соларић пријања уз ставове Франческа Соавеа, па тај начин Злайна къижица представља истовремено српски бонтон и преноси Србима идеје које је ширио Соаве, а које су везане како за просветљени деспотизам Јосипа II, тако и за филозофију Кондијака коју је пригрлио те емпиризам Џона Лока.

Кључне речи: Злайнаја књижица, Павле Соларић, Франческо Соаве, бонтон.

С обзиром да је саิм Павле Соларић, најближи сарадник Доситеја Обра-

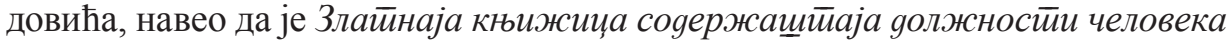

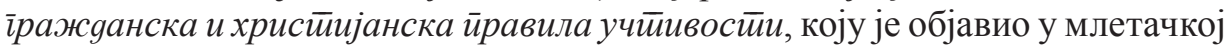
штампарији Пана Теодосија 1813. године (СолАРић 1813), „рођена сестрица Итике, посљедњега изданија нашега незабвенога сократическога старца“ (СолАРит 2019: 361), тј. Доситеја, сасвим је логично да се увек, кад се говори о Ейици Доситеја Обрадовића, доводи у везу и Соларић. Десет година пре Соларићеве књижице Доситеј је код истог издавача објавио Ейику или филозофију наравноучитетелну (ОБРАдовит 1803) и истакао на насловној страни да је то дело издато „по систему г. професора Соави“. Српска наука о књижев-

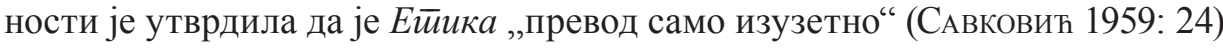
дела итало-швајцарског етичара, филозофа и педагога Франческа Соавеа (Francesco Soave, 1743-1806), Istituzioni di logica, metafisica, et etica (SoAve 1791) ${ }^{1}$

${ }^{1}$ Соаве је затим ово дело објавио такође у Милану, код истога издавача, али овај пут у четири тома (SOAVE 1793a; 1793б; 1794в; 1794г). УП., међутим, напомене за ОБрадовић 2007: 
и да само једна седмина текста садржи приближну вредност оригиналу, а да једна трећина текста представља „слободну репродукцију низа Соавиних идеја“" (САвковић 1959: 25), док је такође једна трећина дела Доситејева творевина. Како истиче Душан Иванић (2007: 187), на основу анализе Доситејеве Ейике коју је начинио Јован Савковић, „нашег просвјетитеља нису привлачила ни теоријска питања ни научне процедуре расправе у Соавиној Етици, већ практична питања самоспознавања и дјеловања човјека у животним околностима, о чему говори изричито на многим страницама своје књиге“, а све то у сврху моралног и просветног препорода српског народа. Надовезујући се, дакле, на Савковића (1959: 30-31), Иванић (2007: 188) закључује да је Ейика пример „како је Доситеј прерађивао и асимиловао дјело једног западноевропског научника за потребе унапређења српске културе“ (уп. Ћорит 2013: 574).

Доситеј Обрадовић је, како анализира Николета Кабаси (2013: 148) која такође полази од чланка Јована Савковића, артифекс и прерађивач Соавине Eйике, где се налазе „Локове и Кондијакове идеје, иако у нешто блажем облику“. Николета Кабаси се усредсредила на анализу трећег дела Доситејеве Ейике у коме се говори о „Чесном человјеку“ и „Должностима положителним“. По ауторки (155), Обрадовић, дакле, присваја оригинални текст да би затим приредио и изложио личну идеалну перспективу и наставио сопствену културну битку: победити, заједно са глађу и оно што често до ње доводи, то јест незнање; наиме, додатак проширује у дивулгативном кључу његово лично излагање, да би показао да се преводом не остварује само директно упоређивање двају аутора, већ и интеракција и разговор између аутора и читаоца.

Ауторка закључује (162) да је резултат Доситејевог превода-прераде такав да се изопачује и емотивни утицај текста и да, док с једне стране Доситеј често скраћује и сажима текст, „у другим случајевима он продужава, моралише, удаљава се од теме убацујући делове који су блискији читаоцу, додајући идеји есенцијалну изражајност и живост, изостављајући уско научне тачке филозофске целине“.

Од ставова Јована Савковића полази и Снежана Милинковић (2013: 168) која истиче: „Додавања, одузимања и, уопште, преиначавања текста оригинала не представљају, дакле, довољан разлог да се Доситејева верзија Ейике не посматра као превод и то више него типичан за доба у којем је настао“. Милинковић (173) сматра да се управо у малим наративним цели-

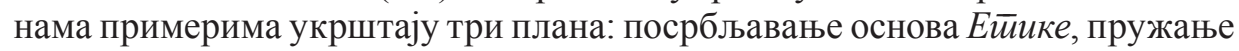
наука и подуке ,двама идеалним, различитим типовима публике“. Ауторка овом приликом наглашава Доситејев ,'прекрасан' језички, а самим тим и преводилачки дар“ (176).

188: „Етику је [Соаве] издао као шесту књигу својих дјела, Istituzioni di logica, metafisica, et etica (Instituzioni di etica, Venezia: Stamperia di Giacomo Storti, 1800; 168 str.).“ 
За разлику од Доситејевог превода-прераде, кад се говори о Злайној књижици Соларићевој, ради се о доследном преводу Соавиног дела Trattato elementare dei doveri dell'uomo e delle regole della civiltà, proposto ai giovanetti per il modello esemplare, ad uso delle scuole della Lombardia austriaca (Основни трактат о дужностима човека и правилима друштва, за младе који треба да буду на пример, за школе у аустријској Ломбардији) које је изашло 1786. године у Милану ${ }^{2}$ и објављиван је све до 1883. у 18 издања (TASCA 2004: 28; уП.: ВOTTERI 1999: 146; PANCERA 1985: 313)33. Прво млетачко издање је из 1790, код издавача Грациозија (GRAZIOSI 1790), а следила су затим и друга издања које је Соларић имао на располагању у Венецији, као издање из 1795. године код штампара Ђакома Стортија (SтоRті 1795), и посебно издање које је Соларићу тада било најсвежије, из 1809. године, код издавача Гаетана Мартинија (Gaetano Martini) па се да претпоставити да је управо ово издање (SOAVE 1809) могло да послужи Соларићу као предложак.

Каже Душан Иванић (2019: 679) да је Соларић превео овај трактат под утицајем Доситејеве Ейике. По питању односа оригинала и превода, Павле Поповић (2000: 35) је прокоментарисао да је наслов Соларићеве књиге „нешто измењен према оригиналу“, а за сам превод је рекао: „Соларић се, рекао бих, у свом преводу послужио Доситијем (пор. изразе: отрицателни, положителни, за negativi, positivi), али је Доситијева реченица лепше и чистије казана“ (36). Никола Андрић је, пак, сматрао да је Злайнаја књижииа „пријевод философске садржине“ (ANDRIĆ 1902: 146/44) и док је „превађао“ (147/45) ово Соавино дело, Соларић је додао неколико страница предговора, тј. Преgисловија (СолАРић 2019: 362-365) у коме је призвао пажњу српских читалаца на позитивне последице доброг васпитања, указујући да у првом реду о томе треба да брину родитељи, а они родитељи који немају времена да се баве васпитањем деце показују да не схватају основну дужност свог живота. Соларић критикује и сурово поступање занатлија према својим шегртима јер сматра да је то остатак варварских времена. Велики значај придаје учитељима и сматра да би било пожељно да се у свим јавним училиштима предаје по овој Злайној књижици, а сваки родољубиви Србин треба да је показује ономе који је не поседује, и на тај начин би се Срби приближили Спартанцима код којих није било устаљених училишта већ је сваки човек могао на било ком другом месту да подучава било кога.

После предговора долази превод Соавиног дела који се састоји из два дела: први део говори „О Должностима Человека“, према Богу, према себи и према другима, а други део о правилима учтивости. Каже Никола Андрић:

O pravilima učtivosti bio je u slavenosrpskom periodu izdavan velik broj knjiga. I Dositejeva „Hristoitija“, što ju je Obradović preveo još god. 1770.

\footnotetext{
2 Претпоставља се да је то прво издање овог Соавиног дела (ВоTTERI 1999: 146), а издање из 1788. године (SoAve 1788) се најчешће наводи као прво.

${ }^{3}$ Само у Италији је у XIX веку изашло 450 разних издања дела која су имала за тему лепо понашање, в.: PAternoster, Saltamacchia 2017.
} 
s novogrčkog - a izdao ju tek god. 1826. Konst. Pejčić kao posmrče Dositejevo - nije ništa drugo nego zbirka pravilâ pristojnosti. Ovakvih knjiga bilo je u ono doba dosta u srpskoj književnosti, te je nekolicinu nabrojao St. Novaković na 204. strani svoje „Književnosti“ (ANDRIć 1902: 46-47).

И заиста, у Посветии Стефану Гавриловићу, Михаилу Павковићу и Луки Кисићу, Соларић (2019: 361) је истакао да „народу славеносерпскому недостававше руководство, које ће он одобрити к употребленију в наставленији своје јуности“. „Он“ је Доситеј Обрадовић, а кад се зна да су превод и предговор настали пре издавања књиге, тј. марта 1811 , могуће је претпоставити да је Соларић очекивао одобрење Доситејево који је, како знамо, умро 28. марта те године.

Ово руководство о правилима учтивости је у ствари прелаз од филозофско-књижевне традиције педагошко-моралног модела хуманистичких speculum principis-a („,огледало владара“), у којима се разматрало васпитање владара и остварење, заснивање владавине на врлинама (в. QUAGLIONI 1987; уп. Giosi 2016), до бонтона, а који има дугу историју. Лепо понашање је почело да се развија као аутономни идеал тек на почетку модерног доба, када је дошло до сједињења морала и врлина (honestum) са спољним облицима понашања (decorum), па су почеле да се објављују књиге и књижице које су ишле у том правцу, као нека врста граматике понашања. Исти случај је у нашој средини, па конкретно Соларићевом бонтону претходи Доситејев, тј. горе наведена Христиоийија сиреч блай обичаји коју је Доситеј завршио у Далмацији 1770. године и која је објављена тек 1826. За ово дело је Веселин Чајкановић (2013: 63) рекао да је „византијски savoir-vivre, из XVIII века“ и додао је свој, не баш позитиван суд о томе:

Доситеј је с овим преводом учинио рђав избор. У њему имамо пуно аргументата е contrario за невероватну запуштеност и подивљалост друштва коме је Хрисииоитиија намењена. Са каљавом садржином стоје у складу и две несимпатичне рекламе у почетку оригинала, једна од стране типографа, друга од аутора. За овакав прилог нашој књижевности и није, ваљада, Доситеј толико одговоран - њему се бар не може мнойо пребацити што се није уздигао изнад друштва у коме су овакве књиге могле бити примане!

Тихомир Остојић (1911; уП. и Џонић 1923; ПАПАдРиАНОс 2014), подстакнут Решетаровом претпоставком, разматрао је извор Доситејеве Христиоийије и упоредио је са Блаїонравијем (Беч 1786) Димитрија Дарвара, а оба дела потичу из истог извора, тј. од грчког аутора Антонија Византијског који је написао Христоитију 1708, и која је штампана 1780 (Кићовит 1929; Китромилидис 2013: 30). Каже Мирјана Д. Стефановић (2008: 206) да је вероватно „најтачније мишљење које говори о том како је рукописно ширена христоитија Антонија Византијског, али и као уџбеник у грчким школама, могла да буде извор нашем Доситеју“. Нићифор Вукадиновић (1923: 59) је 
подвукао да се не зна ко је с латинског превео Христоитију на простогрчки, „јер се његов рукопис, по коме је Антоније Виз. удесио своју Христоитију, изгубио“, а сви рукописи до данас садрже „само Христоитију Антонијеве редакције на старогрчком, или прераде са исте“.4

Нићифор Вукадиновић је тврдио да је извесно да је Антоније Византијски превео дело Еразма Ротердамског, De civilitate morum puerilium (O културном васпитању деце, 1530). ${ }^{5}$ То је дело холандски теолог, филозоф и филолог Еразмо Ротердамски (1466-1536) написао за сина Хенрија Бургундског и садржавало је прописе како да се дете понаша у друштву одраслих. Књига је имала огроман успех и била је преведена на многе језике, са преко 130 издања, заједно са бројним имитацијама, преводима, и адаптацијама (уп. СтолАновић 1991). Прво енглеско издање је из 1532. године под насловом A Little Book of Good Manners for Children, а прво руско из 1788. Ово је васпитни текст који је смишљен за приватну сферу и за катехизис и бави се понашањем човека у друштву и односи се посебно на физички декор: покрети тела, гестикулација, одевање, израз лица. Еразмо је истицао добре и лоше манире узимајући примере из друштвеног живота (уп. Тимотијевић 2013).

Еразмово дело је аутентични трактат лепог понашања и био је модел и за једно друго дело, које је било предложак за руководство Франческа Соавеа које је превео Соларић, и оба дела представљају два главна auctoritates што се тиче лепог понашања (ВоTтER 1999: 119). Реч је о делу Galateo overo de' costumi (Галатео или о манирима, 1558) италијанског, тачније фирентинског књижевника и архиепископа Ђованија Дела Казе (Giovanni Della Casa, 1503-1556). Назив Галайео потиче од личног имена Галеаца Флоримонтеа (Galeazzo Florimonte, 1484-1565), католичког бискупа који је подстакао Дела Казу да напише овај први италијански прави уџбеник лепих манира и коме је Дела Каза на тај начин учинио омаж. Галайео је део хуманистичке традиције (Pons 1990), пре свега педагошких трактата, као наведени speculum principis, и припада оном жанру који у англосаксонској средини познат као advisory или conduct literature, као што је било Еразмово дело, и које се односило на сферу свакодневног понашања. Каже Нићифор Вукадиновић (1923: 61) да се у неким издањима Христиоит̄ије на крају налази опаска:

Христоитија је исто што и код Италијана Galateo названа књига. Ово је сасвим умесно поређење. Il Galateo је у италијанској књижевности класично дело. [...] Имао је многе имитаторе у Италији и вани. Премда је у Италији већ од тринаестог столећа било писаца који су се више-мање позабавили овим предметом, али на писање овог дела - Il Galateo, - који тај предмет третира потпуно и у заокругљеном облику, биће да је још више имало утицаја тада већ добро познато Еразмово дело.

${ }^{4}$ В.: Стефановић 2008: 206: „[...] запажено је већ да је и тај уџбеник имао свој извор у латинском изању Еразма Ротердамског“.

${ }^{5}$ Кићовић 1929: овде се као година издања доноси 1526. 
Нићифор Вукадиновић је на истом месту поменуо и Соларићеву Злайнају књижсиу: „И то је превод, наиме с италијанскога, од Франћеска Соаве.“

Ђовани Дела Каза је са својим Галайеом започео прави књижевни жанр који ће као такав носити име управо „галатео“ у XIX веку. Као што је у Немачкој, захваљујући томе што је Адолф Франц Фридрих Лудвиг Книге (Adolf Franz Friedrich Ludwig Knigge, 1752-1796) 1788. године објавио три тома дела о лепом васпитању и манирима, Über den Umgang mit Menschen, термин „книіе “ од тада постао синоним за књиге бонтона ${ }^{6}$.

Њему, пак, претходи, тридесет година раније, један други чувени трактат о лепом понашању који је такође често прештампаван, Il libro del cortegiano (Књига дворанина, 1528), чији је аутор Балдасаре Кастиљоне (Baldassar Castiglione, 1478-1529). Но док се Еразмов педагошки програм теоретски обраћа свима, Галайео, као и Кастиљонеов Дворанин обраћају се искључиво џентлменима, који треба да науче да манифестирају и споља свој статус супериорности. Нарочито је ова тенденција дошла до изражаја у Француској где се веома рано развила буржоазија која је била блиска аристократији и која је истицала софистицираност обичаја и понашања. Почели су да се јављају сложени функционални ритуали реципрочног препознавања статуса (правила предности, правила удварања, правила позивања у госте и сл.) и ширио се канон који је племство пратило. У историји књижевности термин bienséances је кључни термин класичне теорије књижевности и друштвеног живота XVII века, који указује оно што може да се ради и говори у одређеној ситуацији, лепо понашање и добар укус.

Два главна ренесансна италијанска уџбеника лепог понашања, Галайео Дела Казе и Дворанин Кастиљонеа, иако доста слични међу собом, разликују се у суштини у једном елементу: док је Дворанин био замишљен за двор, за унутрашњост двора (в. Ossola 1978; VANNI 2011), дотле је Галайео прекорачио зидине двора, али и времена. И један и други уџбеник имали су за циљ да подуче љубазност, како племића, тако и других сталежа. И један и други уџбеник су кодификацију лепог понашања заснивали на норми која се код Кастиљонеа звала „sprezzatura“ (самоувереност, али и омаловажавање), а код Дела Казе је одговарала идеји дискреције или умерености. Дела Казин Галайео је остао модел и важна референцијална тачка лепог понашања све док са просветитељством и француском револуцијом није дошло до промене концепције индивидуе и улоге човека у друштву. ${ }^{7}$ Вредности које су се пре тога заснивале на крвној линији, замењене су вредностима које је требало да се базирају на заслузи и раду, па стога су друштвени односи постајали све сложенији јер их више није контролисала хијерархија већ су (били) подложни промени. Осетила се онда потреба да се пишу „нови галатеји“ тј. нови бонтони за „нове људе“ ХІХ века, међу којима једино мерило

${ }^{6}$ Италијански превод: KNIGGE 1816.

7 Дела Казин Галатео је у првих 50 година XIX година изашао у 60 издања. B.: SANTOsuosso 1979. 
које је одређивало те нове људе било управо лепо васпитање. Онда није случајно да је већ почетком XIX века, тачније 1802. изашао један нови галатео, Nuovo Galateo (GioJA 1802) политичара и историчара Мелкиора Ђоје (Melchiorre Gioja, 1767-1820. ${ }^{8}$ Његов бонтон је нов у смислу да се дистанцира од претходног аристократског модела васпитања, а за основу се позива на разум који треба да диктира норме лепог понашања, па се љубазност почела сматрати делом процеса цивилизације.

Као што је био популаран бонтон лаичког и јакобинског Мелкиора Ђоје, тако је у исто време постао популаран један други бонтон, хришћанског и филохабзбуршког Франческа Соавеа, коме је Марија Терезија дала задатак 1775. да организује школе у Ломбардији. Године 1786. Соаве је добио задужење, на основу указа Јосипа II, да припреми уџбенике за основне школе, између осталог и уџбеник лепог васпитања који је требало да одражава однос државе и цркве и у коме је било пожељно показати до које границе је сваки сталеж требало да се уздржи да би се омогућила боља друштвена слога.

Соавин бонтон је први од уџбеника лепог понашања с краја XVIII и почетком XIX века који је изложио везу између љубазности и хришћанских вредности (в.: ВOTTERI 2006), пре свега у двема основним вредностима од којих се прва налази у Јеванђељу по Матеју 22, 35-40 (Вук 1945: 41):

35. И упита један од њих законик кушајући га и говорећи:

36. Учитељу! која је заповијест највећа у закону?

37. А Исус рече му: љуби Господа Бога својега свијем срцем својијем, и свом душом својом, и свом мисли својом.

38. Ово је прва и највећа заповијест.

39. А друга је као и ова: љуби ближњега својега као самог себе.

40. О овима двјема заповијестима виси сав закон и пророци.

О другом концепту вредности читамо у Јеванђељу по Марку 12, 28-34 (82):

28. И приступи један од књижевника који их слушаше како се препиру, и видје да им добро одговара, и запита га: која је прва заповијест од свију? 29. А Исус одговори му: прва је заповијест од свију: чуј Израиљу, Господ је Бог наш Господ једини;

30. И љуби Господа Бога својега свијем срцем својијем и свом душом својом и свијем умом својијем и свом снагом својом. Ово је прва заповијест. 31. И друга је као и ова: љуби ближњега својега као самога себе. Друге заповијести веће од овијех нема.

32. И рече му књижевник: добро, учитељу! право си казао да је један Бог, и нема другога осим њега;

33. И љубити га свијем срцем и свијем разумом и свом душом и свом снагом, и љубити ближњега као самога себе, веће је од свију жртава и прилога.

\footnotetext{
${ }^{8}$ Ђоја је преправио свој Галатео три пута: 1820, 1822, 1827.
} 
34. А Исус видјевши како паметно одговори рече му: нијеси далеко од царства Божијега. И нико више не смијаше да га запита.

Соаве у овом смислу идентификује хришћанско братство са „негативним дужностима“ и „позитивним дужностима“, тј. онако како је Павле Поповић подвукао да је Соларић превео, тј. као „отрицателне дужности“ и „положителне дужности“. Негативне дужности би биле дакле оне које појмимо као уздржање да нешто урадимо, док позитивне би се изједначавале са солидарношћу. Односно и конкретно: негативне дужности налажу нам да се уздржимо од тога да увредимо другога на било који начин („налажу нам воздержаватије от овижденија другаго на кој нибуд начин“, СолАРић 1813: $35)$ и да не чинимо никоме ништа што би му сметало (,не чинити нигда ни кому ничеса, што би га ословило“, 36); позитивне дужности налажу нам да свима чинимо најбоље што можемо (,налажу нам творити свим величајше добро што можемо“, 42). На те се дужности позива Соларић у „Предисловију“ Злайној књижици где каже: „Прва погодба, под којом ми стојимо како у каковом либо простом, тако најпаче у многосоставном гражданском содружеству, и преимуштествено у христијанском вјероисповједанију, јест, познавати должности своје и исполњавати““ (СолАРић 2019: 362). Соларић говори о „дужностима нашим“ имајући у виду децу као „драгоцјени залог народње и господарствене надежде“ (363). Потреба да се ова књижица усвоји у школама по Соларићу је везана за дужност љубави према народу:

Када буду сва сија у повсемјестној вједомости и у дјелопроизводству посредје славеносрпскога народа нашега? Најскорјеје ондје гдје ми имамо обштенародња училишта, ако у ова, како је причина надјејати се, настојашта уведе се књижица. А и посвуда другдје у вједомости не поздно, ако сваки Србин, кој ову књижицу у руке добије, држећи себи за дужност народољубија, њу и другим покаже, и који не умјеју уважавати ју, им о њој ум разбистри; от којега самога дружељубнога разбистриванија ума може чајати се и оно дјелопроизводство (364-365).

О тим дужностима је Соаве још 1774. наговестио свом пријатељу Убалду Касини (Ubaldo Cassina, 1736-1824), који је такође у Парми предавао моралну филозофију:

Ti ringrazio della traccia speditami delle tue lezioni, la quale mi piace, benché io abbia preso un metodo un po' diverso. Distinti i doveri dell'uomo pio, dell'uomo saggio e del buon cittadino ho omessa per quest'anno la trattazione de' primi lasciando a' metafisici la cura di recare le dimostrazioni dell'esistenza di Dio, e ai teologi quella di assegnare il culto che gli si deve; ma l'anno venturo forse converrà che li tocchi. Fo consistere i doveri, o piuttosto l'interesse dell'uomo saggio nel ben regolare l'immaginazione e le passioni [...]. Finirò con ciò che riguarda l'uomo saggio coll'esaminare se tutti possano giungere alla felicità, e quali ne siano i mezzi. I principi del diritto naturale daranno cominciamento alla parte che riguarda il buon cittadino; 
ma a questa parte non ho ancora pensato. Eccoti in breve un picciolo abbozzo di quel ch'io vo lavorando. ${ }^{9}$

У Соавиној књизи, па и у Соларићевом преводу, иду прво дужности а онда правила лепог понашања. У издању из 1855 , међутим, које је изашло са промењеним насловом, Il galateo, o trattato elementare dei doveri dell'uomo (Галатео, или основни трактат о дужностима човека, SOAVE 1855), ред је обрнут па прво иду правила лепог понашања, а после дужности (уп.: TASCA 2004: 60), што значи да је дошло до промене приоритета у друштву. Очигледно је да је Соаве полагао велику важност на формирање доброг грађанина и ако погледамо ту Злайнају књижииу, како гласи у Соларићевом преводу, видећемо да Соаве није имао на уму грађанина у садашњем смислу речи јер овде се ради пре свега о дужностима: дужностима према Богу, према самом себи - а што обухвата индивидуални пут ка срећи, која се састоји у мирном и задовољном срцу: „Благополучије на свјету овом не состоисе у именију многих богатств, или многих честеј, но у именију спокојна и задовољна сердца“ (СолАРић 1813: 33), те дужности према другима. Дужности

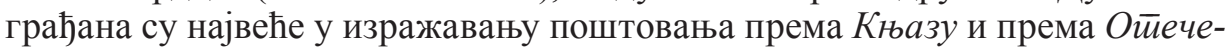
cйву: „У време мира мак он је дужан вљусти се, да оно не обезчести или не возмути зљими дјељи, и старатисе вмјесто тога, да оно прослави своими добродјетелми и своими услугами, и да му сдјеласе полезњим своими труди“ (47). У овом смислу, практично није било места за права, ни човека ни грађанина. О томе како је Соаве разматрао права види се из његовог дела које је 1793. објавио под псеудонимом, о правој идеји француске револуције, Vera idea della rivoluzione di Francia (SOAVE 1793), где говори о прелазу од природне независности до друштвене зависности (137): по Соави једина права би била она која зависе од установљења друштва у коме се људи налазе. Соаве се дакле залагао пре него за декларацију права, за декларацију дужности (127) и у просветљеном деспотизму, као што је била владавина Јосипа II, Соаве је нашао модел за кога се надао да ће довести до обнове и еманципације друштва.

У тој својој бризи за формирањем грађана Соаве је настојао да уједини сензуалистичку теорију Кондијака са хришћанском традицијом. На Соавеа

${ }^{9}$ Нав. у: Остинели 2007: 21: „Захваљујем ти на нацрту твојих предавања који си ми послао, и који ми се свиђа, иако сам се ја одлучио за један мало други метод. Поделио сам дужности побожног човека, мудрог човека и доброг грађанина, али сам за ову годину пропустио да се бавим овим првим и оставио сам метафизичарима бригу да изложе доказе о постојању Бога, а теолозима бригу да одреде доследну веру; али следеће године ће можда бити пожељно да их мало преправим. Мислим на дужности, или пре на потребу разборитог човека да правилно регулише машту и страсти [...]. На крају ћу размотрити то што се односи на разборитог човека и да ли сви могу да дођу до среће, као и која су средства потребна за то. Начела природног права биће на почетку оног дела који се односи на доброг грађанина; али о том делу још нисам размислио. Ево ти укратко једна мала скица онога на чему тренутно радим““ (прев. П. Л.) 
је утицала филозофија Етјена Бона де Кондијака (Etienne Bonnot de Condillac, 1768-1780; в.: ВоTTERI 1999: 191; TASCA 2004: 60), који је живео и предавао у Парми, и кога је Соаве лично познавао јер је био позван као предавач поезије на Академији пажева и на Универзитету у Парми где је упознао овог чувеног француског свештеника, филозофа и члана Академије. Са агрономом и академиком Карлом Аморетијем (Carlo Amoretti, 1741-1816), године 1776. Соаве је приредио за штампу Кондијаков прелиминарни говор за педагошку енциклопедију Cours d'études pour l'instruction du prince de Parme (в. MURATORI 1776).

Термин сензуализам је изражен у Кондијаковом делу Traité des sensation (1754), где су преузети многи концепти из теорије емпиризма либералног енглеског филозофа Џона Лока који је у ствари полазна тачка Кондијака. Кондијак, међутим, уводи у своје дело извесне промене које су суштинске: иако прихвата разликовање идеја од осећаја, која долазе директно из спољњег света кроз чула, и умне идеје које их ствара ум кад размишља о свом деловању, Кондијак оспорава да је размишљање извор знања које се разликује од чула. За разлику од Лока, дакле, за Кондијака наша спознаја није независна од чула, што доводи до гносеолошког апсолутног сензуализма: не само идеје, већ све духовне делатности (сећање, суд, апстрактни облици везани за емотивни живот) нису ништа друго до трансформисани осећаји, који су у ствари, кроз бол и задовољство, везани за задовољење физиолошких потреба човека.

Одраз Локових и Кондијакових теорија у овој „књижици“ о лепом понашању, како ју је Соларић скромно ословио, и која је захваљујући његовом преводу постала српски бонтон, потврђује одлуку нашег преводиоца и филолога да је назове „златнаја“. Ова књижица заслужује далеко већу пажњу наше историје књижевности и златна је из више разлога: пре свега што нам, кроз превод дела Франческа Соавеа, преноси одраз тада актуелних филозофских теорија у Европи и упућује нас ка додатној контекстуализацији у том погледу. Ово значи да управо рецепција дела Франческа Соавеа у српској средини, прво код Доситеја и Соларића, изискује даља истраживања (в. КЕРковић 2014), већ због саме чињенице што је Соаве био задужен за реформе школства по указу бечког двора. И не само то: Соаве је био под утицајем германске културне средине и у његовом делу је очигледан одраз дидактичко-моралне књижевности немачког говорног подручја, што такође тражи додатна истраживања о преводима и прерадама те рецепцији ове врсте литературе и културних модела у српској средини с краја XVIII и у првој половини XIX века, а што би потврдило да ова Злайнаја књижища, у суштини, садржи у себи много више од дужности човека и правила учтивости. 


\section{ИЗВОРИ}

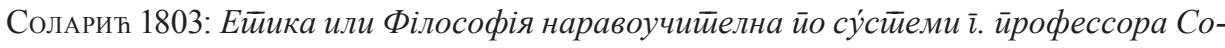
ави Досіөеемъ Обраяовичемъ изgат̄а. У Венеціи: у Грекославенской ту́пографіи г. Пано Өеодосія, 1803.

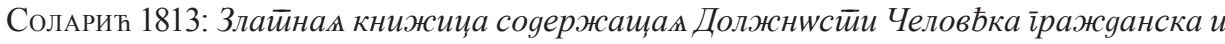

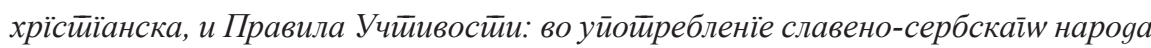

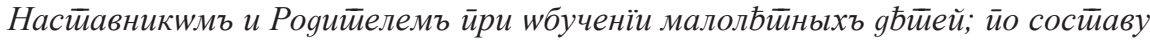
Г. Учийеля Ф. Сшавы: Пакломъ Соларичемъ изgана. Въ Мльткахъ: Писмены Греко-Славенскї^ Печатни Паны Өеодосїева, [1813].

СолАрић, Павле. Сабрана gјела. Д. Иванић и И. Бјелаковић (прир.). Београд: Задужбина Доситеј Обрадовић, 2019.

\section{$*$}

Soave 1809: Trattato elementare dei doveri dell'uomo di Francesco Soave C. R. S. Ad uso delle scuole d'Italia. In Venezia: Presso Gaetano Martini. Librajo a San Samuele, 1809.

\section{ЦИТИРАНА ЛИТЕРАТУРА}

ВукАдиновић, Нићифор. Доситејева Христоитија и њени узори. Прилози за књижевност̄, језик, истиорију и фолклор III (1923): 48-81.

Иванић, Душан. Напомене. Доситеј Обрадовић. Совјейи зяраваі̄o разума. Слово йоучителено йосйоgина Георйја Јоакима Цоликофера. Ейика. Београд: Задужбина Доситеј Обрадовић, 2007, 165-196.

КАБАси, Николета. Доситеј Обрадовић, artifex и прерађивач Соавине Еӣике. Доси-

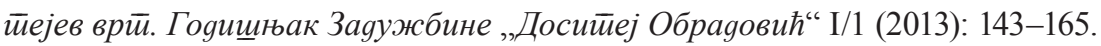

Керковић, Александар. Наg филозофијом нарави йо систиему йрофесора Соаве изgа-

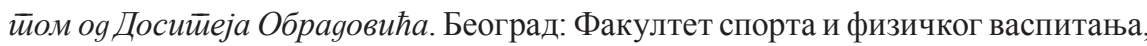
2014.

Китромилидис, Пасхалис М. Доситеј Обрадовић и грчко просветитељство. Душан

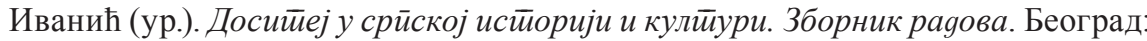
Задужбина Доситеј Обрадовић, 2013, 25-31.

Кићовић, Мираш. Нићифор Вукадиновић, Доситејева Христоитија и њени узори.

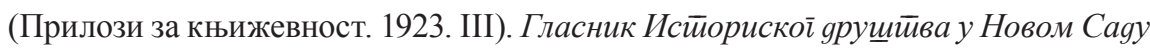
2 (1929): 133-134.

Милинковић, Снежана С. Још неколико напомена о Доситејевом преводу „Основа

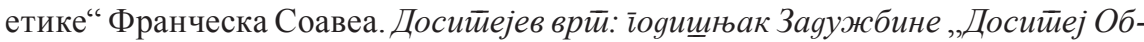
раяовић“ 1/1 (2013): 166-186.

Нови Завјет̄ Госйоgа нашеїа Исуса Христиа. Вук Стеф. Караџић (прев.). Њујорк Лондон: Савет Библиских друштава, 1945. 


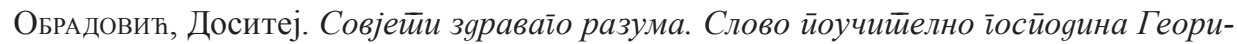
іије Јоакима Цоликофера. Ейика. Књига трећа. Душан Иванић (прир.). Београд: Задужбина Доситеј Обрадовић, 2007.

Остолић, Тихомир. Извор Доситејеве „Христоитије“. Бранково коло XVII/387/6 (1911): 524-536.

ПАПАДРиАнос, Иоанис А. Учени Грци Димитрије Дарвар и Георгије Захариадис. Њихов допринос славеносербској књижевности, Cyrillomethodianum: Studies on the History of Greek-Slavic Relations XIX (2014): 101-108.

Поповић, Павле. Злайна кьижица Павла Соларића. Павле Поповић. Сабрана gела.

Књ. V. Нова књижевности. I. Og Досийеја gо Вука и Сйерије. Предраг Палавестра (прир.). Београд: Завод за уџбенике и наставна средства, 2000, 35-36.

САвковић, Ј[ован]. После уређења Соавине и Доситејеве „Етике“. Ковчежић II (1959): 24-31.

Стефановит, Мирјана Д. Напомене. Доситеј Обрадовић. Сӣиси из Далмаиије. Пройовеgи и бесеgе. Зайиси и белещке. Фрайменйи из Србије. V. Мирјана Д. Стефановић (прир.). Београд: Задужбина Доситеј Обрадовић, 2008, 191-216.

Столановић, Миодраг. Доситеј и Еразмо Ротердамски. Научни сасӣанак славистиа у Вукове дане 19/2 (1991): 493-498.

Тимотијевић, Мирослав. Значај Доситејеве „Христоитије“у прихватању манира као културног капитала српског нововековног грађанства. Душан Иванић (ур.).

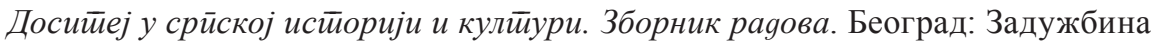
Доситеј Обрадовић, 2013, 87-105.

Ђорић, Марија. Етика Доситеја Обрадовића. Душан Иванић (ур.). Досийеј у срӣској истиорији и кулӣури. Зборник раяова. Београд: Задужбина Доситеј Обрадовић, 2013, 573-592.

ЧАлкановић, Веселин. О Доситејевим грчким и римским изворима. Сйоменица Досиӣеју Обраgовићу. Београд: Правни факултет Универзитета, Центар за издаваштво и информисање, 2013, 47-70.

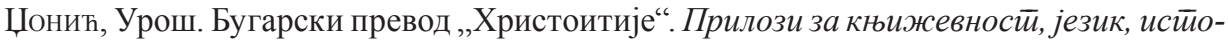
рију и фолклор III (1923): 229-231.

ANDrić, Nikola. Život i književni rad Pavla Solarića. Zagreb: Tisak Dioničke tiskare, 1902. BotTERI, Inge. Galateo e galatei. La creanza e l'instituzione della società nella trattatistica italiana tra antico regime e stato liberale. Roma: Bulzoni, 1999.

BotTeri, Inge. Tra creanza e doveri dell'uomo: Francesco Soave. Amedeo Quondam (a cura di). Giovanni Della Casa: un seminario per il centinario. Roma: Bulzoni, 2006, $1-24$.

Condotta da tenersi nella società, opera del Sig. Adolfo Knigge, traduzione libera dal tedesco di R.A., corredata di note d'un italiano. 2 voll. Milano: presso A. F. Stella, 1816.

GiojA, Melchiorre. Nuovo Galateo. Milano: Presso Pirotta e Maspero, 1802.

Giosi, Marco. La tradizione degli specula principum e la Institutio principis christiani di Erasmo da Rotterdam. Educazione. Giornale di pedagogia critica. V/2 (2016): 43-66. 
Istituzioni di etica di Francesco Soave c.r.s. regio professore. vol. 3. Milano: Giuseppe Marelli, 1794.

Istituzioni di logica di Francesco Soave c.r.s. regio professore. vol. 1. Milano: Giuseppe Marelli, 1793.

Istituzioni di metafisica di Francesco Soave c.r.s. regio professore. vol. 2. Milano: Giuseppe Marelli, 1793.

Opuscoli metafisici di Francesco Soave c.r.s. regio professore. vol. 4. Milano: Giuseppe Marelli, 1794.

Ossola, Carlo. Il luogo della corte. Maurizio Achille Romani (a cura di). Le corti farnesiane di Parma e Piacenza (1545-1622): potere e società nello stato farnesiano. Vol. I. Roma: Bulzoni, 1978, xxxix-I.

Ostineldi, Marcello. L'epistolario di Francesco Soave. Scuola ticinese. Periodico della Divisione della scuola, XXXVI/III, Marzo-Aprile (2007), 19-21.

PANCERA, Carlo. Educazione dei costumi e insegnamento delle virtù. Gian Paolo Brizzi (a cura di). Il catechismo e la grammatica, vol. I. Istruzione e controllo sociale nell'area emiliana e romagnola nel '700. Bologna: il Mulino, 1985, 287-346.

Paternoster, Annick, Francesca Saltamacchia. (Im)politeness formulae and (im)politeness rules: metadiscourse and comnventionalisation in 19th Century Italian conduct books. Elena Maria Pandolfi, Johanna Miecznikowski, Sabine Christopher, Alainm Kamber (eds.). Studies on Language Norms in Context. Frankfurt am Main: Peter Lang, 2017, 263-301.

Piano ragionato di Educazione del sig. abate di Condillac, tradotto dal sig. abate Giuseppe Muratori. Scelta di opuscoli interessanti tradotti da varie lingue. Milano: nella stamperia di Giuseppe Marelli, 1776, vol. x, 5-37.

Pons, Alain. Le thème de la comunication dans le Galatee de Giovanni Della Casa. Savoir vivre I (sous la dir.) Alain Montandon. Meyzieu: Césura Lyon Edition, 1990, 11-23.

QuAgLIONI, Diego. Il modello del principe cristiano: gli specula principum fra Medioevo e prima Età Moderna. Modelli nella storia del pensiero politico. vol. 1, Firenze: Olschki Ed., 1987, 103-122.

Santosuosso, Antonio. The Bibliography of Giovanni Della Casa, Readers and Critics: 1537-1957. Firenze: Olschki, 1979.

SoAve, Francesco. Il galateo, o trattato elementare dei doveri dell'uomo. Piacenza: presso Solari. 1855.

SOAVE, Francesco. Istituzioni di logica, metafisica, et etica. Milano: Stamp. G. Marelli, 1791. SoAve, Francesco. Trattato elementare dei Doveri dell'Uomo e delle regole della civiltà, proposto ai giovanetti per modello esemplare. Milano: presso Giuseppe Marelli e Gaetano Motta, 1788.

TASCA, Luisa. Galatei. Buone maniere e cultura borghese nell'Italia dell'Ottocento. Firenze: Le Lettere, 2004.

Trattato Elementare Dei Doveri Dell'Uomo di Francesco Soave. Venezia: Stamperia G. Graziosi, 1790. 
Trattato elementare dei doveri dell'uomo di Francesco Soave C.R.S. Ad uso delle scuole. Venezia: Nella stamperia di Giacomo Storti, 1795.

VANNI, Laura. La corte come istituzione educativa: la formazione del cortigiano. Studi sulla formazione 2 (2011): 127-141.

Vera idea della rivoluzione di Francia di Francesco Soave c.r.s. Napoli: Presso Luigi Coltellini, 1793.

Persida S. Lazarević Di Đakomo

ZLATNAJA KNJIŽICA (1813) OR SERBIAN ETIQUETTE BOOK

Summary

This paper analyzes Zlatnaja knjižica (Golden booklet, 1813), a Serbian translation of the work of the Italo-Swiss pedagogue and writer Francesco Soave (1743-1806), Trattato elementare dei doveri dell'uomo e delle regole della civiltà (1786). The author of the translation is Dositej Obradović's closest friend and associate Pavle Solarić (1779-1821), who explains the importance of this booklet in his "Preface" to the work. In both his translation and preface, Solarić adheres to the views of Francesco Soave so that the Golden booklet constitutes both a book of etiquette for the Serbs as well as a summary of Soave's beliefs which were based on the enlightened despotism of Joseph II and the philosophy of Condillac that had also been embraced by John Locke's empiricism.

Università degli Studi "G. d'Annunzio" Chieti-Pescara persida.lazarevic@unich.it 